\title{
|リチウム水素化物を添加し不安定化処理した水 素吸蔵黒鉛の水素貯蔵特性
}

\section{Hydrogen storage properties of hydrogenated graphite destabilized by mixing with lithium hydride}

\author{
宮岡裕樹*, 礒部繁人*, 市川貴之 ***, 藤井博信 **
}

Hiroki Miyaoka*, Shigehito Isobe*, Takayuki Ichikawa*** and Hironobu Fujii**

\begin{abstract}
Hydrogen storage properties of the ball-milled mixtures composed of hydrogenated nano-structural graphite $\left(\mathrm{C}^{\text {nano }} \mathrm{H}_{x}\right)$ and lithium hydride $(\mathrm{LiH})$ were examined from thermodynamic and structural points of view, where the $\mathrm{C}^{\text {nano }} \mathrm{H}_{x}$ was synthesized by ball-milling graphite powder under hydrogen atmosphere. Since hydrogen atoms in the $\mathrm{C}^{\mathrm{nann}} \mathrm{H}_{x}$ and $\mathrm{LiH}$ are strongly bonded with each host atom, heating up to $>600^{\circ} \mathrm{C}$ is necessary to release hydrogen from each solid product. The $\mathrm{C}^{\text {nano }} \mathrm{H}_{x}$ and $\mathrm{LiH}$ composites desorbed hydrogen and hydrocarbon gases below $400{ }^{\circ} \mathrm{C}$ with about 9.4 mass $\%$ weight loss. The $2: 1$ composite of the $\mathrm{C}^{\mathrm{nan}} \mathrm{H}_{x}$ and $\mathrm{LiH}$ reversibly stored hydrogen with an effective capacity of about 4.5 mass $\%$ at $350{ }^{\circ} \mathrm{C}$. No evident peaks were observed in XRD profiles after the dehydrogenation, indicating that the nano-structural feature remained after dehydrogenation due to formation of $(\mathrm{CLi})^{\text {nano }}$ clusters. However, only the $\mathrm{LiH}$ phase was crystallized after rehydrogenation at $350^{\circ} \mathrm{C}$. From these results, it is concluded that hydrogen in the composites is destabilized by a novel interaction between the $\mathrm{C}^{\mathrm{nano}} \mathrm{H}_{x}$ and $\mathrm{LiH}$ in a nanometer scale, and is desorbed at lower temperatures than each of the components. Therefore, this $\mathrm{Li}-\mathrm{C}-\mathrm{H}$ system can be recognized to be a new family of hydrogen storage materials.
\end{abstract}

KEYWORDS : Hydrogen storage material, Graphite, Nano-structure, Mechancal milling, Gas desorption properties

\section{1. 緒 言}

現在, 化石燃料に代わる次世代エネルギー媒体の1つとして水 素が注目されて抢り,水素の貯蔵・輸送技術に関する研究が世界中 で盛んに行われている。近年では, 特にリチウム $(\mathrm{Li})$, ホウ素 $(\mathrm{B})$, 炭素 (C) といった軽元素で構成された水素貯蔵材料が有望視さ れている。その理由は, 軽元素水素貯蔵材料が, 従来の $\mathrm{LaNi}_{5}$ な どの遷移金属を基礎とした合金材料に比べ, 構成元素が非常に軽 いため, 重量当たりの水素貯蔵密度が高く, 車載用としての実用 化が期待されるからである。これらの中で, 炭素は地球上に豊富 に存在し,安価, かつ安全に利用できることから, 実用化を目的と した水素貯蔵材料の原料としては理想的であると言える。

炭素を原料とした水素貯蔵材料は, 1997年の A. C. Dillon らに よるカーボンナノチューブ (CNT) 1) の水素貯蔵特性の報告以降, 単層カーボンナノチューブ (SWCNT) 1)-5), 多層カーボンナノチ ユーブ (MWCNT) 6),7), カーボンナノファイバー (CNF) 8)-10), 活 性炭 $(\mathrm{AC})$ 11), 12), ナノ構造化グラファイト $\left(\mathrm{C}^{\text {nano }} \mathrm{H}_{x}\right)$ 13) - 17) など, いわゆる,ナノ構造を有する炭素材料の水素貯蔵特性の研究報告 が多数なされてきた。ナノ構造炭素系水素貯蔵材料は, 物理吸着
を用いる材料系と化学吸着を用いる材料系の 2 つ分類される。 前者は, 分子状水素を直接ナノ構造化した炭素材料の表面 (グラ フェンシート面) に吸着するため, 吸着エネルギーが数 $\mathrm{kJ} / \mathrm{mol} \mathrm{H}_{2}$ と非常に小さく, $5.0 \mathrm{mass} \%$ 以上の水素を貯蔵するためには液体 窒素温度程度の低温が必要とされる。このため, 室温付近で高容 量貯蔵を実現することは困難である18)。一方, 後者は原子状水素 を炭素との化学結合により貯蔵するため, 高容量に貯蔵できるが, $\mathrm{C}-\mathrm{H}$ 結合が強く水素化状態が安定であるため, 水素を切り離すた

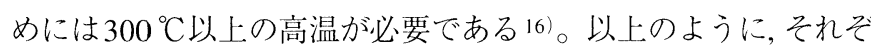
れ一長一短があり, 現時点では, 国際的な目標值と考えられてい る「水素貯蔵量 5.5 mass \%以上, 動作温度 $150{ }^{\circ} \mathrm{C}$ 以下」 19), 20) に迫 る物質の開発には至っていない。

これらの炭素系水素貯蔵材料の中で,われわれはこれまでナ, 構造化グラファイト $\left(\mathrm{C}^{\mathrm{nano}} \mathrm{H}_{x}\right)$ に注目し研究を進めてきた。これ は, 高純度グラファイト粉末を水素雾囲気下でボールミリング法 を用いて粉砕処理することにより作製され，化学吸着により $7 \mathrm{mass} \%$ もの多量の水素を吸蔵させることが可能である ${ }^{13)} 。$ 方, $\mathrm{C}^{\mathrm{nan}} \mathrm{H}_{x}$ はミリング処理により構造破壊が進行し，ナノスケー ルでのみ秩序を有するという特徽を併せもっている13)。 $\mathrm{C}^{\mathrm{nan} 0} \mathrm{H}_{x}$

* 広島大学大学院先端物質科学研究科： =739-8530 東広島市鏡山1-3-1

* Department of Quantum Matter, ADSM, Hiroshima University : 1-3-1 Kagamiyama, Higasihiroshima, Hiroshima 739-8530, Japan

**広島大学先進機能物質研究センター (IAMR) : T 739-8530 東広島市鏡山1-3-1

** Institute for Advanced Materials Research, Hiroshima University : 1-3-1 Kagamiyama, Higasihiroshima, Hiroshima 739-8530, Japan 
中の水素の收蔵状態は, これまで, 中性子回折実験 21), プロトン 核磁気共鸣実験 22) および, 赤外分光実験23)により調査されてお り,機械粉砕処理により多量に作製されるナノ構造化されたグラ フェンのエッジ部に, - $\mathrm{CH}$ あるいは, $-\mathrm{CH}_{2},-\mathrm{CH}_{3}$ といった官能基 (岑化水素基) の形で水素が吸蔵されていることが明らかにされ ている。これらの結合水素は, 昇温に伴い $300 \sim 800^{\circ} \mathrm{C}$ という広 い温度領域において, 多くは水素 $\left(\mathrm{H}_{2}\right)$ の形で放出されるほか,一 部はメタンガス $\left(\mathrm{CH}_{4}\right)$ やエタンガス $\left(\mathrm{C}_{2} \mathrm{H}_{6}\right)$ といった炭化水素と して放出される14)。また, 一度放出された水素系ガスを, 温度と 圧唰御のみで同程度まで再吸蔵させることにはこれまで成功 していない16)。したがって, $\mathrm{C}^{\text {nano }} \mathrm{H}_{x}$ の 7 mass \%という吸蔵水素 量に注目すれば, 実用化材料として非常に有望であるが,「水素 放出に高温を要する」,「水素吸蔵・放出の可逆性がそしい」とい う課題を克服することが必要不可欠であるとされてきた。すな わち, $\mathrm{C}^{\text {nano }} \mathrm{H}_{x}$ を水素貯蔵材料として利用するためには, $\mathrm{C}^{\mathrm{nano}} \mathrm{H}_{x}$ の 不安定化を図る必要がある。

本研究に扔いて, $\mathrm{C}^{\text {nano }} \mathrm{H}_{x}$ の不安定化を目的として添加した水 素化リチウム $(\mathrm{LiH})$ 自身は, $12.7 \mathrm{mass} \%$ という高容量の水素を 吸蔵可能であるが, 比較的安定なイオン結晶であるために, 熱分 解によって水素を放出させるには $650{ }^{\circ} \mathrm{C}$ という高温が必要とさ れ, 水素販蔵材料として用いるには不向きであると考えられてき た。しかし，2002年にChenらによって， $\mathrm{Li}_{3} \mathrm{~N}$ を用いた新規水素 貯蔵材料の報告がなされた24)(この系は,リチウム $(\mathrm{Li})$, 窒素 $(\mathrm{N})$ および水素 $(\mathrm{H})$ 原子を含むため Li-N-H 系と称されている)。こ の $\mathrm{Li}_{3} \mathrm{~N}$ の水素化反応は, 以下に示した2段階の反応により進行し, $\mathrm{LiNH}_{2}$ およびLiH という水素化状態に不均化していくことで可逆 に水素が吸蔵・放出される。

$$
\mathrm{Li}_{3} \mathrm{~N}+\mathrm{H}_{2} \leftrightarrow \mathrm{Li}_{2} \mathrm{NH}+\mathrm{LiH} \quad\left(\Delta H=-165.0 \mathrm{~kJ} / \mathrm{mol} \mathrm{H}_{2}\right)
$$

$\mathrm{Li}_{2} \mathrm{NH}+\mathrm{H}_{2} \leftrightarrow \mathrm{LiNH}_{2}+\mathrm{LiH} \quad\left(\Delta H=-44.5 \mathrm{~kJ} / \mathrm{mol} \mathrm{H}_{2}\right)$

このChenらの報告を基に, われわれは水素化に伴うエンタルピ 一変化のより小さな反応 (2) 式の反応に注目し, Li-N-H系材料 の水素放出機構についての調査を精力的に行い, $\mathrm{LiH}+\mathrm{LiNH}_{2} \leftrightarrow$ $\mathrm{Li}_{2} \mathrm{NH}+\mathrm{H}_{2}$ の水素放出反応が以下に示す 2 つ素反応からなる ことを明らかにした。

$$
2 \mathrm{LiNH}_{2} \leftrightarrow \mathrm{Li}_{2} \mathrm{NH}+\mathrm{NH}_{3}
$$

$$
\mathrm{LiH}+\mathrm{NH}_{3} \leftrightarrow \mathrm{Li}_{2} \mathrm{NH}+\mathrm{H}_{2}
$$

ここで, $\mathrm{LiH}$ は $\mathrm{NaCl}$ 型のイオン結晶構造を有しており, 上述したよ

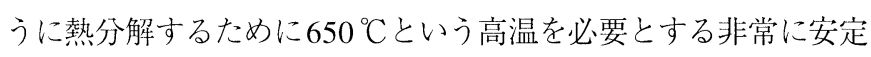
な物質である。しかし，このようなイオン構造を有する LiHは， 極性分子である水によって容易に不安定化され, 事実, 室温で水 素を放出すると同時に水酸化リチウム $(\mathrm{LiOH})$ を形成する。つ まり，まず（3）式に示したように $\mathrm{LiNH}_{2}$ の分解によって極性を有す るアンモニア $\left(\mathrm{NH}_{3}\right)$ 分子が生成され, この $\mathrm{NH}_{3}$ 分子の極性が $\mathrm{LiH}$ と相互作用することによって, LiHのイオン結晶が不安定化され,
$\mathrm{Li}_{2} \mathrm{NH}$ が件成されると阔時に $200{ }^{\circ} \mathrm{C}$ 付近で水絭が放山されている のである25)-27)。

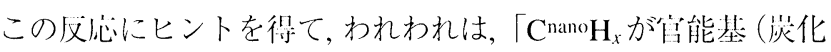
水素基）として水素を吸蔵している」という特徴に注目した。つ まり，これらの官能基は極性を有するため, 上記 (4) 式のアンモ ニア $\mathrm{NH}_{3}$ の代替物質として, 水素化グラファイト $\mathrm{C}^{\mathrm{nano}} \mathrm{H}_{x}$ を用い れば,ナノメートル領域で $\mathrm{C}^{\text {nano }} \mathrm{H}_{x}$ と $\mathrm{LiH}$ とが相互作用することに よって, 拉いの固相中の水素が不安定化され得るのではないか と考えた。

そこで, 本研究では, $\mathrm{C}^{\mathrm{nano}} \mathrm{H}_{x}$ の有する課題を改善するために, $\mathrm{C}^{\mathrm{nano}} \mathrm{H}_{x}$ と $\mathrm{LiH}$ との複合材料を機械的ボールミル法によって創製 し, その水素貯蔵特性の調査を行った。本論文中では, まず, さま ざまな混合比で機械的ボールミル法により作製した $\mathrm{C}^{\text {nano }} \mathrm{H}_{x}-\mathrm{LiH}$ 複合化試料の昇温ガス放出特性および構造特性から, 最適な混合 比をいかにして設計するかについて検討する。次に, 水素および重 水素を用いた複合化試料の水素同位体ガス放出特性の比較から， 水素放出機構について考察する。さらに, 水素吸蔵・放出特性 (サイクル特性)について, 熱力学的, 構造的特性の視点から議論 を展開する。なお, 本系はリチウム $(\mathrm{Li})$, 炭素 $(\mathrm{C})$ および水素 (H) を含む無機化学系材料であるため, 以後 Li-C-H系材料と称 し議論を進める。

\section{2. 実験方法}

本研究における,ナノ構造化グラファイト $\left(\mathrm{C}^{\mathrm{nano}} \mathrm{H}_{x}\right)$ は, 高純度 グラファイト (99.999\%, STREAM CHEMICALS) 300mg を, $\mathrm{ZrO}_{2}$ (ジルコニア：直径 $8 \mathrm{~mm}$ ) 製ボール 20 個とともにクロム鋼 製容器 (SKD-11) に入れ, 振動型ミリング装置 (SEIWA GIKEN Co. Ltd., RM-10) を用いて, 水素圧 $1.0 \mathrm{MPa}$ 下で 80 時間ボールミリ ング処理することによって作製した17),28)。さらに, 水素の放出 起源を調査するために, 重水素 $\left(\mathrm{D}_{2}\right)$ 圧 $1.0 \mathrm{MPa}$ 下でグラファイト を 80 時間ミリング処理することで $\mathrm{C}^{\text {nano }} \mathrm{D}_{x}$ を作製した。次に， $\mathrm{C}^{\text {nano }} \mathrm{H}_{x}-\mathrm{LiH}$ (および $\mathrm{C}^{\text {nano }} \mathrm{H}_{x}-\mathrm{LiD}, \mathrm{C}^{\text {nano }} \mathrm{D}_{x}-\mathrm{LiH}$, および $\mathrm{C}^{\text {nano }} \mathrm{D}_{x}-\mathrm{LiD}$ ) 複合材料は $\mathrm{C}^{\text {nano }} \mathrm{H}_{x}$ (あるいは, $\mathrm{C}^{\text {nano }} \mathrm{D}_{x}$ ) と水素化リチウム $(\mathrm{LiH}$ : $95 \%$, Aldrich)（あるいは, 重水素化リチウム（LiD：98％， Aldrich)）を合計で $300 \mathrm{mg}$ となるように秤量し, ジルコニア製ボ ール 20 個とともにクロム鋼製容器に入れ, 遊星型ミリング装置 (Fritch, P7) を用いて, 水素圧1.0MPa（あるいは, アルゴンガス圧 $1.0 \mathrm{MPa})$ 下で, 2 時間ミリング処理することにより作製した。ま た, 混合比 (mol 比) の最適化のために, $\mathrm{C}^{\text {nano }} \mathrm{H}_{x}: \mathrm{LiH}=1: 4$, $1 ： 2,1: 1,2: 1,4: 1$ となるよう混合した試料をミリング処 理により作製した。サイクル特性調査のために, 真空下, $350{ }^{\circ} \mathrm{C}$ で8 時間保持する脱水素化処理, および $3.0 \mathrm{MPa}$ の水素圧下, $350{ }^{\circ} \mathrm{C}$ で 8 時間保持する再水素化処理を 1 ～回繰り返し行った。なお， すべての試料は, 酸化や水分などによる影響を防ぐために, 高純 度アルゴンガス (99.9999％以上) が充填されたグローブボック ス (Miwa MFG, MP-P60W) 中で取り扱った。

作製された Li-C-H 系複合化試料の熱力学特性は, TG-DTA (Thermogravimetry-Differential Thermal Analysis, 熱重量·示差 
熟分析：Rigaku, TG8120) 装置および, TG-DTA装置に接続され たTDMS (Thermal Desorption Mass Spectroscopy, 界温脱離ガス 筫星数分析：Anelva, M-QA200TS) 装置を用いて周榃した。测 足は，高純度へリウムガス (99.9999％以上)をキャリアガスとして 用い, 昇温速度 $5^{\circ} \mathrm{C} / \mathrm{min} に て$ 行った。さらに, 水素の結合状態の 調查は, FT-IR (Fourier Transform-Infrared spectroscopy, フーリ 工変換赤外吸収分光：Perkin-Elmar, Spectrum One) 測定により行 った。FT-IR 測定には, 試料に希釈剂として KBr (99mass％)を 加え,メノウ乳鉢を用いて混合したものを用いた。なお, 空気な どの影響を最小限に抑えることによって試料の本質的な特性評 価を行うために, 以上の装置はすべて, 高純度アルゴンガスを充 填したグローブボックス中に設置されている。試料の構造特性 は, XRD (Powder X-Ray Diffraction, 粉末X線回折：Rigaku, RINT-2100, CuK $\alpha$ radiation) 測定により調査を行った。XRD測定 には, 酸化などの影響を防ぐため, あらかじめグローブボックス 中でポリイミドシート (Kapton®, DuPont-Toray Co., LTD.) を用 いて, 空気に曝されないように密閉処理した試料を用いた。

\section{3. 結果・考察}

\subsection{Li-C-H系材料の混合比の検討}

Fig.1 (a) に $\mathrm{C}^{\text {nano }} \mathrm{H}_{x}: \operatorname{LiH} の$ 比が $1: 4,1: 2,1: 1,2: 1,4: 1$ の試料の昇温脱離ガス放出プロファイル，(b)にTG-DTA スペク トル，(c)にミリング処理後, および (d) に脱水素化後のXRD プ ロファイルを示す。まず,すべての混合比の試料において共通し て言えることは, 約 $350{ }^{\circ} \mathrm{C}$ 水素の放出ピークか観測され,この水素 放出のピーク温度付近で, 強度が著しく減少する微量の炭化水素 の放出が観測されていることである。また, 最も大きな差異は, 混 合比が $\mathrm{C}^{\text {nano }} \mathrm{H}_{x} / \mathrm{LiH} \leq 1$ の試料 $\left(\mathrm{C}^{\text {nano }} \mathrm{H}_{x}: \mathrm{LiH}=1: 4,1: 2,1: 1\right)$ と $\mathrm{C}^{\text {nano }} \mathrm{H}_{x} / \mathrm{LiH}>1 .\left(\mathrm{C}^{\text {nanoo }} \mathrm{H}_{x}: \mathrm{LiH}=2: 1,4: 1\right)$ の試料の間で現 れている,つまり, 前者はFig.1 (b) のDTA プロファイルに見られ るように, 水素放出のメインピークより高い約 $450{ }^{\circ} \mathrm{C}$ の温度で鋭 い吸熱ピークを示している。このことは, Fig.1 (d) に示したよう に, 前者の試料 $\left(\mathrm{C}^{\mathrm{nano}} \mathrm{H}_{x} / \mathrm{LiH} \leq 1\right)$ の水素放出後のXRD プロファイ ルに, $\mathrm{Li}_{2} \mathrm{C}_{2}$ に相当するピークが顕著に観測されている点に対応 する。つまり, Fig.1 (b) の高温側で見られる吸熱ピークは $\mathrm{Li}_{2} \mathrm{C}_{2}$ の結晶化に起因したものであると考えられる。一方, 後者の試料 $\left(\mathrm{C}^{\mathrm{nano}} \mathrm{H}_{x} / \mathrm{LiH}>1\right)$ では, 水素放出のメインピークより高温では, 際立った熱反応ピークは見られず, Fig.1 (d) に示した水素放出後 のXRD プロファイルにおいても, Li と C の化合物に由来するピ 一クも, $\mathrm{C}^{\mathrm{nan}} \mathrm{H}_{x}$ で見られたグラファイトの結晶化も観測されてい ない。以上のことより, $\mathrm{Li}$ 金属原子がナノ構造を有する $\mathrm{C}^{\mathrm{nan} o} \mathrm{H}_{x}$ と相互作用し, ナノスケールで複合化した状態 (CLi) nanoになっ ていると推察される。

さて, Fig.1（b）から明らかなように $\mathrm{C}^{\mathrm{nano}} \mathrm{H}_{x}$ と $\mathrm{LiH}$ との混合比 の值に関係なく, $350{ }^{\circ} \mathrm{C}$ の水素放出に伴って, Fig.1 (b) のDTA スペ クトルに顕著な吸熱ピークが観測されている。これは, 水素吸蔵状 態に比べ, 水素放出状態がより不安定であることを示しており， 熱力学的に水素を再吸蔵させることが可能であることを示唆し (a)

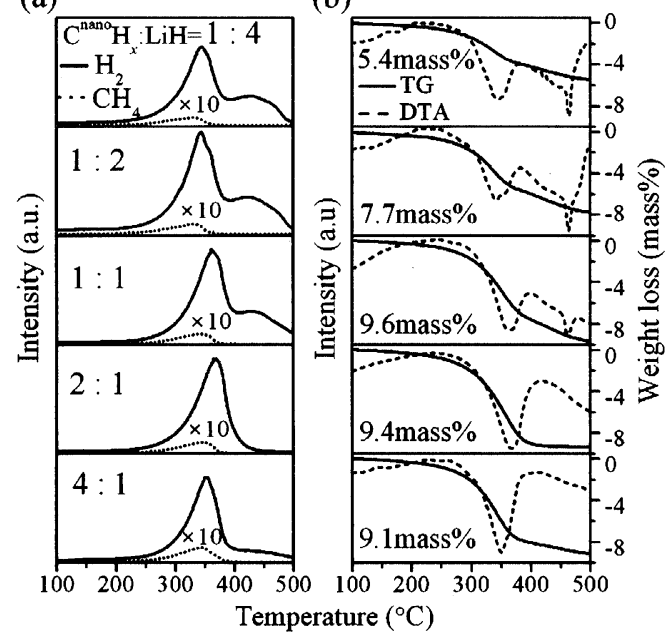

(c)

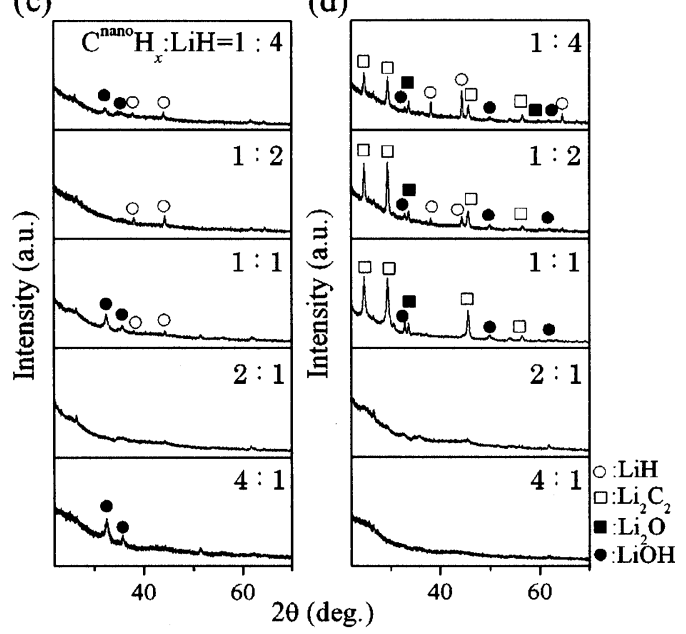

Fig.1 (a) TDMS spectra of the $\mathrm{C}^{\text {nano }} \mathrm{H}_{x}$ and $\mathrm{LiH}$ composites $\left(\mathrm{C}^{\text {nano }} \mathrm{H}_{x}: \mathrm{LiH}=1: 4,1: 2,1: 1,2: 1,4: 1\right)$ show hydrogen and hydrocarbons desorption profile up to $500{ }^{\circ} \mathrm{C}$. (b) TG (solid line)-DTA (broken line) spectra of those composites show weight loss and transferring heat in gases desorption reaction with increasing temperature up to $500{ }^{\circ} \mathrm{C}$. (c) XRD profiles of as-milled composites and (d) dehydrogenated composites indicate variation of structure.

ている。つまり, $\mathrm{C}^{\text {nano }} \mathrm{H}_{x}-\mathrm{LiH}$ 複合系の水素吸蔵放出反応が可逆 的に起こり得ることを示唆している。また, Fig.1 (b) に示したそ れぞれの試料のTG スペクトルから, 水素, および微量の炭化水素 放出による重量減少の值は $\mathrm{C}^{\mathrm{nano}} \mathrm{H}_{x} / \mathrm{LiH}$ が 1 より小さな複合化試 料においては, 混合比の減少に伴い減少することがわかる。

以上の結果より, 水素貯蔵材料として用いるには, 可逆な水素 貯蔵能を示す $\mathrm{C}^{\text {nano }} \mathrm{H}_{x} / \mathrm{LiH}>1$ である $\mathrm{C}^{\mathrm{nano}} \mathrm{H}_{x}$ と $\mathrm{LiH}$ の比が $2 ： 1$ および $4: 1$ の試料がより適していると言える。また, 実用化材 料としての重要な因子である水素貯蔵重量密度を考慮すると, 構 成する物質はより軽い元素系のほうが実用上好ましい。つまり， $\mathrm{LiH}$ の存在比が大きいほうが, より高い水素著貯蔵重量密度に導 く。したがって, 混合比 $\mathrm{C}^{\mathrm{nano}} \mathrm{H}_{x} / \mathrm{LiH}$ が2 となる $\mathrm{C}^{\mathrm{nano}} \mathrm{H}_{x}: \mathrm{LiH}=$ $2 ： 1$ の試料を本研究では最適混合比試料として採用した。以後, 
この最適混介比を用いて作製した $\mathrm{C}^{\text {nano }} \mathrm{H}_{x}: \mathrm{LiH}$ が2：1の试料 に焦点を絞って, 水素吸蔵・放出特性について議論を進める。

\section{$3.2 \mathrm{Li}-\mathrm{C}-\mathrm{H}$ 系材料の水素放出メカニズム}

ト述の $\mathrm{C}^{\text {nano }} \mathrm{H}_{x}$ : $\mathrm{LiH}$ の比が2：1の試料の熱力学特性および 構造特性にに川えて, $\mathrm{C}^{\text {nano }} \mathrm{H}_{x}: \operatorname{LiD}(2: 1)$ および, $\mathrm{C}^{\text {nano }} \mathrm{D}_{x}: \mathrm{LiH}$ (2：1) 試料の $\mathrm{H}_{2}, \mathrm{D}_{2}, \mathrm{HD}$ 放出プロファイルから, Li-C-H 系材料の 水素放出メカニズムについて考察する。Fig.2に上述の水素同位 体ガス放訆プロフイルを示してある。先に記述したように， $\mathrm{C}^{\text {nano }} \mathrm{H}_{x}$ : LiH (2:1) 試料の水素放出ピーク温度は $350{ }^{\circ} \mathrm{C}$ であ $り$, 構成物質である $\mathrm{C}^{\text {nano }} \mathrm{H}_{x}$ と $\mathrm{LiH}$ 単独の場合に比べて, 著しく低 温化している。また, $\mathrm{C}^{\text {nano }} \mathrm{H}_{x}$ のみからの昇温脱離ガス放出スペ クトル 14，16，17）には多量の炭化水素の放出が観測されていたが, $\mathrm{C}^{\text {nano }} \mathrm{H}_{x}-\mathrm{LiH}$ 複合化試料においては, 炭化水素の放出が観測され てはいるものの, その放出量はきわめて少量に抑制されているこ とがわかる $\left(\right.$ Fig.1 (a))。さらに, Fig.2 に示した $\mathrm{C}^{\text {nano }} \mathrm{H}_{x}:$ LiD $(2 ： 1)$ および $\mathrm{C}^{\mathrm{nano}} \mathrm{D}_{x}: \mathrm{LiH}(2: 1)$ 試料のガス放出特性を比較

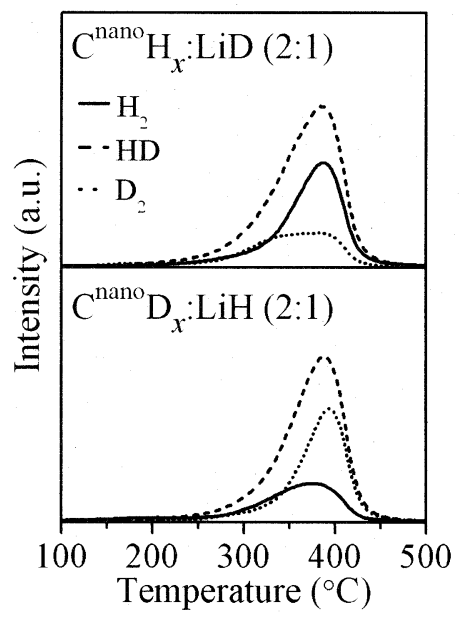

Fig.2 TDMS spectra show $\mathrm{H}_{2}, \mathrm{D}_{2}$ and HD desorption profiles of $\mathrm{C}^{\mathrm{nano}} \mathrm{H}_{x}: \mathrm{LiD}(2: 1)$ (upper) and $\mathrm{C}^{\mathrm{nano}} \mathrm{D}_{x}: \mathrm{LiH}(2: 1)$ (lower) with increasing temperature up to $500{ }^{\circ} \mathrm{C}$.

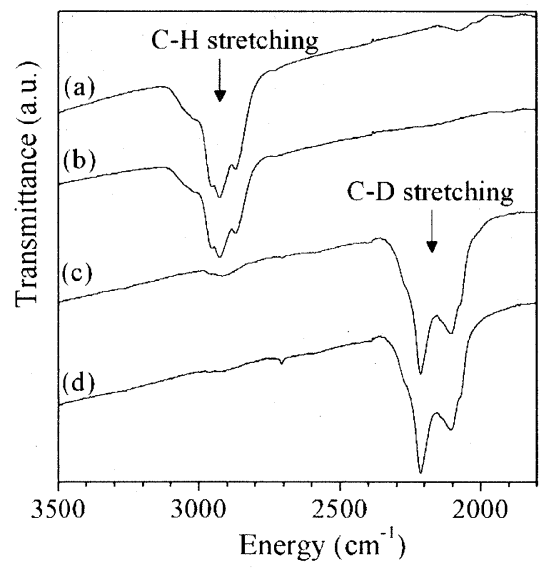

Fig.3 FT-IR spectra of the $\mathrm{C}^{\text {nano }} \mathrm{H}_{x}: \mathrm{LiH}(2: 1)(\mathrm{a}), \mathrm{C}^{\mathrm{nano}} \mathrm{H}_{x}$ : $\operatorname{LiD}(2: 1)(b), C^{n a n o} D_{x}: \operatorname{LiH}(2: 1)$ (c) and $C^{\text {nanoo }} D_{x}:$ $\mathrm{LiD}(2: 1)$ (d) composites reveal the stretching modes of $\mathrm{C}-\mathrm{H}$ or $\mathrm{C}-\mathrm{D}$ groups.

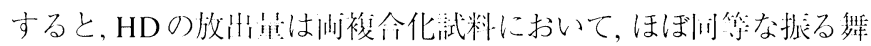
いをふしているのに刘し， $\mathrm{H}_{2}$ と $\mathrm{D}_{2}$ の放计量はそれぞれの䙓令化 試料に抢いてリバーシブルな関係にあることがわかる。また，

Fig.3に小した赤外吸收测定の結果より，これら $\mathrm{C}^{\text {nano }} \mathrm{H}_{x} ： \mathrm{LiD}$ (2：1）および $\mathrm{C}^{\text {nano }} \mathrm{D}_{x}: \operatorname{LiH}(2 ： 1)$ 試料中の水素 $(\mathrm{H})$ および重 水素 (D) 原子が, ミリング処理の際に交換されないことも明らか になっている23)。したがって, Fig.2に示した昇温脱離ガス分析 の結果は, $350{ }^{\circ} \mathrm{C}$ の水素放出が $\mathrm{C}^{\mathrm{nan} o} \mathrm{H}_{x}$, あるいは $\mathrm{LiH}$ 単. 独の固相 からの放出ではなく, $\mathrm{C}^{\mathrm{nano}} \mathrm{H}_{x}$ と $\mathrm{LiH}$ に化学結合していた水素が同 時に不安定化され低温で放出されていることを示唆している。し たがって, $\mathrm{C}^{\mathrm{nano}} \mathrm{H}_{x}: \mathrm{LiH}(2 ： 1)$ 試料では, イオン結晶である $\mathrm{LiH}$ と, $\mathrm{C}^{\text {nano }} \mathrm{H}_{x}$ 中の炭化水素基 $\left(-\mathrm{CH}_{2},-\mathrm{CH}_{3}\right)$ が有する極性とが相互 作用することで, C-H およびLi-H 結合がともに不安定化し, LiH の分解のみならず $\mathrm{C}^{\text {nano }} \mathrm{H}_{x}$ の炭化水素基も分解することで, 両者 の保持する水素が同時に放出されたものと考えられる。

\subsection{Li-C-H系材料のサイクル特性}

\subsection{1 熱力学特性および構造特性}

Fig.4 (a) に $\mathrm{C}^{\mathrm{nano}} \mathrm{H}_{x}: \operatorname{LiH}(2 ： 1)$ 試料, および脱水素化・再 水素化処理のサイクルを繰り返した $\mathrm{C}^{\mathrm{nano}} \mathrm{H}_{x}: \mathrm{LiH}(2: 1)$ 試料 $\left(1^{\mathrm{st}}, 4^{\mathrm{th}}\right)$ のガス放出プロファイル，(b)にそれら試料のTG-DTA スペクトル，(c) にXRD プロファイルを示す。1４回脱水素化· 再水素化処理を行った後の $\mathrm{C}^{\mathrm{nano}} \mathrm{H}_{x}: \mathrm{LiH}(2: 1)$ 試料のTDMS スペクトルは, $330{ }^{\circ} \mathrm{C}$ 付近および $450{ }^{\circ} \mathrm{C}$ 付近に水素放出ピークを 示す $($ Fig.4 (a))。この2つの水素放出ピークに起因して, DTA ス ペクトルにも2つの吸熱ピークが観測されている。この2段階の 水素放出反応については, 水素放出に伴うエンタルピー変化 $(\Delta H)$

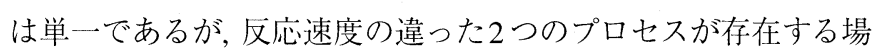
合と, 熱力学的に異なった安定性 $(\Delta H)$ をもつ $2 つ の$ 水素サイト が共存する場合の2つの可能性が考えられる。

1 つ目の可能性は, $350^{\circ} \mathrm{C}$, 真空中で 8 時間脱水素化処理した後の 試料では, $500{ }^{\circ} \mathrm{C}$ で昇温しても, 1 mass \%以下の質量減少しか観 測されなかったという実験的事実を根拠としている。これは, $350^{\circ} \mathrm{C} て ゙ の$ 熱処理によりほぼ脱水素化が完了していることを示唆 している。つまり, $\mathrm{C}^{\mathrm{nan} o} \mathrm{H}_{x}$ と $\mathrm{LiH}$ を複合化した材料は, $350^{\circ} \mathrm{C} て ゙$ 吸蔵した水素を放出し得る $\Delta H$ (熱平衡状態特性)を有する材料 であると考えられる。このような結果が得られているにもかか わらず, Fig.4 (a) に示した再水素化した試料の水素放出プロファ イルでは, 2つのピークが観測されたことから， $\Delta H$ は等価である が, 反応速度の異なる水素放出プロセスが存在している可能性が 示唆されたことになる。

2 つ目は, 本質的に異なる $\Delta H$ を有する 2 種類の水素吸蔵サイト が存在するため, 異なる温度で水素が放出されるという視点から の考察である。これは, Fig.4 (c) に示した脱水素化後のXRD プ ロファイルに $\mathrm{Li}_{2} \mathrm{C}_{2}$ に起因する弱いピークが観測されていること に基づてている。そもそも, Fig.1 (d) に示したような $\mathrm{Li}_{2} \mathrm{C}_{2}$ 結晶 がXRD プロファイルとして確認された試料 $\left(\mathrm{C}^{\mathrm{nano}} \mathrm{H}_{x} / \mathrm{LiH} \leq 1\right.$ の 試料) では再水素化が困難であるという実験結果を得てきた。し たがって, 2 段階の水素放出後に, 結果的に結晶性の $\mathrm{Li}_{2} \mathrm{C}_{2}$ に到達す 
(a)

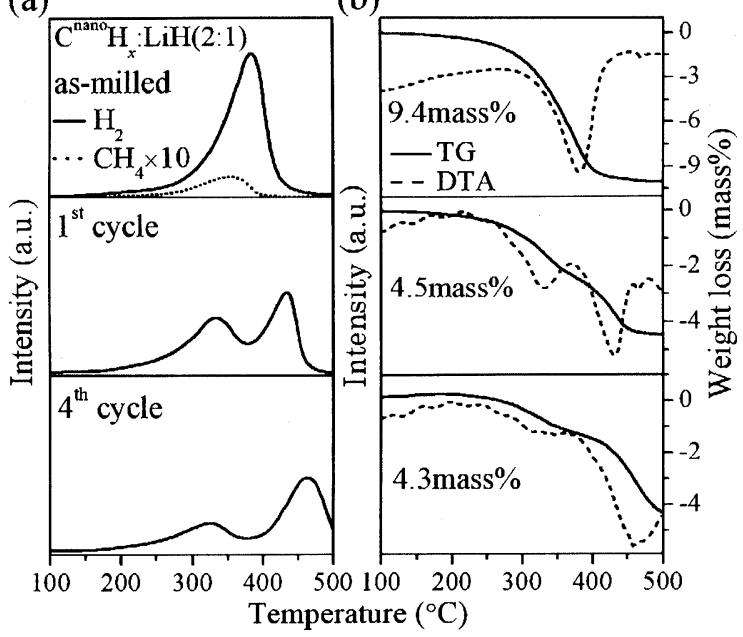

(c)

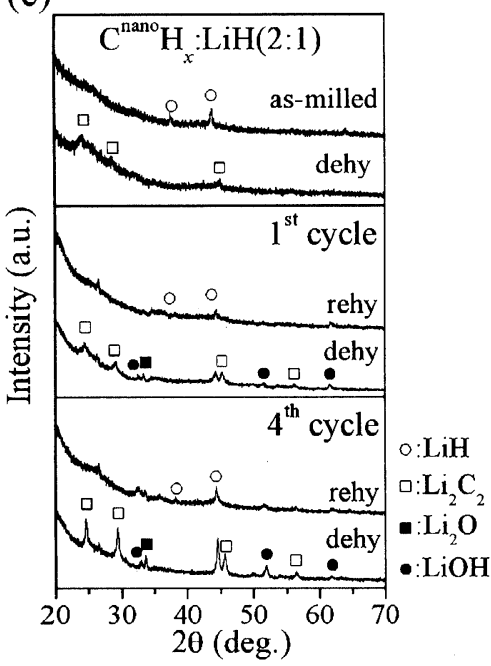

Fig.4 (a) TDMS spectra of the as-milled composite and the cycled composites ( $1^{\text {st }}$ and $\left.4^{\text {th }}\right)$ show gases desorption profile up to $500^{\circ} \mathrm{C}$. (b) TG (solid line) -DTA (broken line) spectra of those composites show weight loss and transferring heat in gases desorption reaction with increasing temperature up to $500{ }^{\circ} \mathrm{C}$. (c) XRD profiles of as-milled or rehydrogenated composites (upper) and dehydrogenated composites (lower) indicate variation of structure.

る水素吸蔵状態と, ナノ複合体 $(\mathrm{CLi})$ nano に到達する水素吸蔵状 態の2 種類が水素吸蔵サイトとして提案できる。

いずれにしても,今後の詳細な調査が必要である。

脱水素化・再水素化のサイクルを1～4回繰り返した $\mathrm{C}^{\text {nano }} \mathrm{H}_{x}$ : LiH (2: 1) 試料は, Fig.4 (a)，(b) に示した水素放出特性に抢い て, 高温側の水素放出が若干高温化しているように見えるものの, 水素放出プロファイルには, 顕著な劣化は観測されなかった。ま た, Fig.4 (c) に示したように, 水素の吸蔵・放出状態にかかわら ず,構造はほぼナノ構造が維持された状態であることがわかった。 ここで,これらの試料の熱放出特性に見られる最も注目すべき点 は, TDMS スペクトルに炭化水素の放出が観測されず，ほぼ水素 のみが放出されていることである (Fig.4 (a))。Fig.4 (b) のミリ ング処理後の試料のTG スペクトルには 9.4 mass \%という大きな

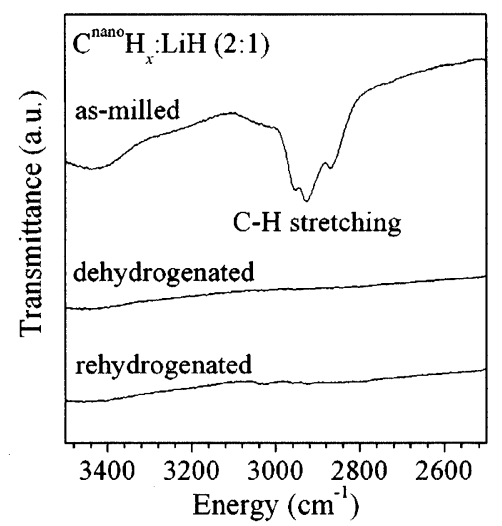

Fig.5 FT-IR spectra of the as-milled, dehydrogenated and rehydrogenated composites indicate variation of $\mathrm{C}-\mathrm{H}$ stretching mode in those composites with de/rehydrogenation.

重量減少か観測されていたが,これにはもち万ん炭化水素の放出 による寄与が少なからず含まれている。しかし, Fig.4 (b) のTG スペクトルに示したように, サイクルを繰り返した後の試料に捛 いては, 水素のみの放出により約 $4.5 \mathrm{mass} \%$ の重量減少か観測さ れている。この結果より, Li-C-H 系材料は少なくとも 4.5 mass \% 程度の水素を可逆に吸蔵・放出することが可能であることが明 らかになった。さらに,これまで示してきた結果は，ミリング処 理後の試料と一度再水素化処理した試料では, $\mathrm{C}^{\mathrm{nan}}{ }^{\circ} \mathrm{H}_{x}-\mathrm{LiH}$ 複合 材料中に扔ける水素の吸蔵状態が異なっている可能性を示唆し ている。しかし, Fig.4 (c) に示した再水素化処理後のXRD プロ ファイルには, LiHに起因するピークが再び観測されてはいるが, グラファイトのナノ構造は依然として維持されているため, XRD プロファイルからは炭素の構造および水素の存在状態について は情報を得ることは不可能である。

\subsection{2 脱水素化・再水素化処理に伴う水素化状態の変化}

水素の結合状態について調査するために,これらの試料のフー リエ変換赤外吸収スペクトル (FT-IR) 測定を行った。Fig.5にミ リング処理後, 脱水素化状態, 㧍よび再水素化状態の $\mathrm{C}^{\text {nano }} \mathrm{H}_{x}$ : LiH $(2 ： 1)$ 試料のFT-IR スペクトルを示す。ミリング処理後の 試料のFT-IR スペクトルには, ナノ構造化グラファイトで観測さ れた- $\mathrm{CH}_{2},-\mathrm{CH}_{3}$ の伸縮振動に起因する吸収スペクトルが観測さ れている。この結果は, $\mathrm{LiH}$ と複合化した後でも, $\mathrm{C}^{\mathrm{nano}} \mathrm{H}_{x}$ の水素 化状態は変化せず, 水素はナノ構造化したグラファイトのグラフェ ンエッジ部に炭化水素基として吸蔵されていることを示唆して いる。一方, 脱水素化処理した試料では, 炭化水素基 $\left(-\mathrm{CH}_{2},-\mathrm{CH}_{3}\right)$ に起因する吸収スペクトルは消失し,さらに, 再水素化した試料 においても，これらの官能基に起因する吸収スペクトルは観測され ていない。つまり,ミリング処理後は, $-\mathrm{CH},-\mathrm{CH}_{2},-\mathrm{CH}_{3}$ といった形 で水素が吸蔵されているが, 再水素化処理後の試料においては, 炭素と水素の結合状態を示すような吸収スペクトルは得られて いない。

以上，これまでの結果を総合し，ミリング処理後の試料と再水 素化後試料の水素放出特性の違いについて考察する。 $\mathrm{C}^{\mathrm{nan} 0} \mathrm{H}_{x}$ 試 料単独の場合, $-\mathrm{CH}_{2},-\mathrm{CH}_{3}$ のような結合状態で水素が吸蔵されて 
おり,これらの水素は昇温に伴って主に炭化水素として放计され る。しかし, $\mathrm{C}^{\text {nano }} \mathrm{H}_{x}: \mathrm{LiH}(2 ： 1)$ 試料では, $\mathrm{C}^{\text {nano }} \mathrm{H}_{x}$ の有する $-\mathrm{CH},-\mathrm{CH}_{2},-\mathrm{CH}_{3}$ の極性が $\mathrm{LiH}$ と相互作用することで分解され, 炭 化水素ではなく水素として低温で放出される。また, $\mathrm{C}^{\text {nano }} \mathrm{H}_{x}$ の 保持する苂化水素基の一部は，ミリング処理による複合化の後に おいても, $\mathrm{LiH}$ と相互作用することなく残存し, 分解されること なく炭化水素として放出されてしまうため, $\mathrm{C}^{\mathrm{nano}} \mathrm{H}_{x}$ 単独に比べ非 常に微荲ながらも炭化水素の放出が観測されると考えられる。一 方, 再水素化した $\mathrm{C}^{\text {nano }} \mathrm{H}_{x}: \mathrm{LiH}(2: 1)$ 試料では, もはや- $\mathrm{CH}_{2}$, $-\mathrm{CH}_{3}$ は存在しないことから, 可能性としては, $\mathrm{LiH}$ が-CH官能基 のみと相互作用する, あるいはナノ構造化グラファイトの触媒作用 により LiHが分解される結果, 微量の炭化水素の放出すら観測さ れない水素のみの放出が実現していると推察される。

\section{4. 結 論}

ナノ構造化グラファイト $\left(\mathrm{C}^{\text {nano }} \mathrm{H}_{x}\right)$ の「水素放出に高温を要す る」,「水素吸蔵・放出の可逆性にそしい」という課題を改善する ため, $\mathrm{C}^{\mathrm{nano}} \mathrm{H}_{x}$ にLiH を添加しミリング処理により複合化したLi$\mathrm{C}-\mathrm{H}$ 系材料を創製し, その熱力学的な特性および構造特性を評価 した。結果として，作製された $\mathrm{C}^{\text {nano }} \mathrm{H}_{x}: \mathrm{LiH}(2 ： 1)$ 試料は, $\mathrm{C}^{\mathrm{nann}} \mathrm{H}_{x}$ および $\mathrm{LiH}$ それぞれの分解温度よりも著しく低温の $350{ }^{\circ} \mathrm{C}$ で水素と微量の炭化水素を放出した。また, 水素放出後は, ナ, 構造状態の炭素 (C $\left.{ }^{\text {nano }}\right)$ と Li が結合することで, 再水素化可能な ナノ複合体 (CLi) nanoを形成していることが明らかになった。し たがって, ミリング処理によりナノスケールで $\mathrm{C}^{\mathrm{nano}} \mathrm{H}_{x}$ と $\mathrm{LiH}$ が密 に接触することで, $\mathrm{C}^{\text {nano }} \mathrm{H}_{x}$ 中の極性を有する炭化水素基が安定な イオン結晶である $\mathrm{LiH}$ と相互作用し, C-H 結合, およびLi-Hがと もに不安定化し，それぞれの構成物質に吸蔵されていた水素が, 著しく低温で放出されると結論される。さらに, Li-C-H系材料は, 水素放出後にナノ構造が維持されるため, $\mathrm{C}^{\mathrm{nano}} \mathrm{H}_{x}$ では不可能であ った水素の再吸蔵が可能となった。 Li-C-H系材料のサイクル特 性において注目すべき点は, 一度脱水素化・再水素化処理を繰り 返した後は, 炭化水素の放出がまったく観測されず水素のみが放 出されることである。つまり, Li-C-H系材料は約 $4.5 \mathrm{mass} \%$ の水 素を $350{ }^{\circ} \mathrm{C}$ で可逆に吸蔵・放出することが可能であると言える。

以上のように, 本研究により Li-C-H 系材料を創製したことに より, $\mathrm{C}^{\mathrm{nann}} \mathrm{H}_{x}$ のもつ「水素放出に高温を要する」,「水素吸蔵・放出 の可逆性が妄しい」という課題は大幅に改善された。さらに, Li-C$\mathrm{H}$ 系材料の水素吸蔵・放出は, これまでにないナノ構造に由来す る新しい相互作用によって引き起こされており, 学術的にも非常 に興味深い。したがって, Li-C-H 系材料の水素貯蔵特性のさら なる向上，执よび本系の研究を基にしたより高性能な新規炭素 系水素貯蔵材料の設計が期待される。

\section{謝 辞}

本研究は, 文部科学省のCOE特別推進研究 (No.13 CE2002), およびNEDO (New Energy and Industrial Technology Development Organization, 新エネルギー・産業技術総合開発機構)の「水素安
企利川管基船技術鬥発」プロジェクトの牥成の基に行われた。

\section{文 献}

1) A. C. Dillon, K. M. Jones, T. A. Bekkedahl, C. H. Kiang, D. S. Bethune and M. J. Heben, Nature 386 (1997) 377-379.

2) Y. Ye, C. C. Ahn, C. Witham, B. Fultz, J. Liu, A. G. Rinzler, D. Colbert, K. A. Smith and R. E. Smalley, Appl. Phys. Lett. 74 (1999) 2307-2309.

3) C. Liu, Y. Y. Fan, M. Liu, H. T. Cong, H. M. Cheng and M. S. Dresselhaus, Science 286 (1999) 1127-1129.

4) A. Zuttel, C. Nutzenadel, P. Sudan, P. Mauron, C. Emmenegger, S. Rentsch, L. Schlapbach, A. Weidenkaff and T. Kiyobayashi, J. Alloys Compd. 330 (2002) 676-682.

5) H. Kajiura, K. Kadono, S. Tsutsui and Y. Murakami, Appl. Phys. Lett. 82 (2003) 1929-1931.

6) P. Chen, X. Wu, J. Lin and K. L. Tan, Science 285 (1999) 91-93.

7) A. C. Dillon and M. J. Heben, Applied Physics a-Materials Science \& Processing 72 (2001) 133-142.

8) C. Park, P. E. Anderson, A. Chambers, C. D. Tan, R. Hidalgo and N. M. Rodriguez, J. Phys. Chem. B 103 (1999) 10572-10581.

9) H. Takagi, H. Hatori, Y. Soneda, N. Yoshizawa and Y. Yamada, Materials Science and Engineering B-Solid State Materials for Advanced Technology 108 (2004) 143-147.

10) H. Takagi, H. Hatori and Y. Yamada, Carbon 43 (2005) 3037-3039.

11) K. A. G. Amankwah and J. A. Schwarz, Carbon 33 (1995) 1313-1319.

12) S. Hynek, W. Fuller and J. Bentley, Int. J. Hydrogen Energy 22 (1997) 601-610.

13) S. Orimo, G. Majer, T. Fukunaga, A. Zuttel, L. Schlapbach and H. Fujii, Appl. Phys. Lett. 75 (1999) 3093-3095.

14) S. Orimo, T. Matsushima, H. Fujii, T. Fukunaga and G. Majer, $J$. Appl. Phys. 90 (2001) 1545-1549.

15) D. M. Chen, T. Ichikawa, H. Fujii, N. Ogita, M. Udagawa, Y. Kitano and E. Tanabe, J. Alloys Compd. 354 (2003) L5-L9.

16) T. Ichikawa, D. M. Chen, S. Isobe, E. Gomibuchi and H. Fujii, Materials Science and Engineering B-Solid State Materials for Advanced Technology 108 (2004) 138-142.

17) S. Isobe, T. Ichikawa, J. I. Gottwald, E. Gomibuchi and H. Fujii, $J$. Phys. Chem. Solids 65 (2004) 535-539.

18) M. Hirscher and B. Panella, J. Alloys Compd. 404 (2005) 399-401.

19) http://www.energy.gov/

20) http://www.nedo.go.jp/

21) T. Fukunaga, K. Itoh, S. Orimo and K. Aoki, Materials Science and Engineering B-Solid State Materials for Advanced Technology 108 (2004) 105-113.

22) E. Stanik, G. Majer, S. Orimo, T. Ichikawa and H. Fujii, J. Appl. Phys. 98 (2005) 044302.

23) N. Ogita, K. Yamamoto, C. Hayashi, T. Matsushima, S. Orimo, T. Ichikawa, H. Fujii and M. Udagawa, J. Phys. Soc. Jpn. 73 (2004) 553-555.

24) P. Chen, Z. T. Xiong, J. Z. Luo, J. Y. Lin and K. L. Tan, Nature 420 (2002) 302-304

25) T. Ichikawa, N. Hanada, S. Isobe, H. Y. Leng and H. Fujii, Journal of Physical Chemistry B 108 (2004) 7887-7892.

26) S. Isobe, T. Ichikawa, S. Hino and H. Fujii, Journal of Physical Chemistry B 109 (2005) 14855-14858.

27) S. Hino, T. Ichikawa, N. Ogita, M. Udagawa and H. Fujii, Chemical Communications (2005) 3038-3040.

28) E. Gomibuchi, T. Ichikawa, K. Kimura, S. Isobe, K. Nabeta and H. Fujii, Carbon 44 (2006) 983-988. 